\title{
Pengembangan Keterampilan Berbahasa Lisan Pada Anak dengan Hambatan Pendengaran melalui Program Terpadu
}

\section{Development of Oral Language Skills in Children with Hearing Impairments Through an Integrated Program}

\author{
Tati Hernawati*, Imas Diana Aprilia, \& Dudi Gunawan \\ Universitas Pendidikan Indonesia, Bandung, Jawa Barat, Indonesia \\ tatihernawati@upi.edu*
}

Naskah diterima tanggal 04/12/2020, direvisi akhir tanggal 27/12/2020, disetujui tanggal 31/12/2020

\begin{abstract}
Abstrak
Anak dengan hambatan pendengaran mengalami hambatan dalam keterampilan berbahasa lisan sebagai dampak langsung dari kehilangan ketajaman pendengarannya. Keterampilan berbahasa lisan ini penting dimiliki anak tersebut agar mereka dapat berkomunikasi dengan lingkungan orang mendengar pada umumnya. Oleh karena itu keterampilan berbahsa lisan ini penting untuk ditingkatkan melalui program yang teruji efektivitasnya. Kegiatan penelitian dilakukan untuk mengetahui efektivitas program terpadu dalam mengembangkan keterampilan berbahasa lisan anak dengann hambatan pendengaran. Metode yang digunakan adalah metode eksperimen dengan posttest design. Jumlah sampel adalah 3 orang, yaitu siswa kelas 3 SLB Negeri Cicendo Bandung, sedangkan teknik pengolahan datanya menggunakan Metode Uji Tanda Median. Hasil penelitian menunjukan bahwa program terpadu dapat meningkatkan keterampilan berbahasa lisan pada anak dengan hambatan pendengaran kelas 3 SLB Negeri Cicendo Bandung, Indonesia. Berdasarkan hasil penelitian ini, guru direkomendasikan untuk mengimplementasikan program terpadu dalam meningkatkan keterampilan berbahasa lisan pada anak dengan hambatan pendengaran, dengan terlebih dahulu melakukan asesmen dan analisis hasil asesmen serta melakukan adaptasi program.
\end{abstract}

Kata kunci: Pengembangan; Keterampilan Berbahasa Lisan; Anak Dengan Hambatan Pendengaran; Program Terpadu.

\begin{abstract}
Children with hearing impairments experience obstacles in their oral language skills due to losing their hearing acuity. These verbal language skills are essential for those children to communicate with the environment where people hear in general. Therefore, it is vital to improving oral language skills through programs that have been tested for their effectiveness. Research activities were carried out to determine an integrated program's effectiveness in developing verbal language skills of children with hearing impairments. The used method was an experimental method with a post-test design. The number of samples was three people, namely 3rd-grade students of SLB Negeri Cicendo Bandung. Processing data techniques were using the Median Sign Test Method. The results showed that the integrated program could improve oral language skills in children with hearing impairments at 3rd grader SLB Negeri Cicendo Bandung, Indonesia. Based on this research results, teachers were recommended to implement the integrated program to improve oral language skills on children with hearing impairments by first conducting an assessment and analysis of the assessment results and adapting the program.
\end{abstract}

Keywords: Development; Oral Language Skill; Children with Hearing Impairments; Integrated Program. 


\section{PENDAHULUAN}

Manusia merupakan makhluk sosial yang dalam kehidupannya selalu membutuhkan interaksi dan komunikasi dengan lingkungannya. Kebutuhan untuk berinteraksi dan berkomunikasi dengan lingkungannya, juga dirasakan oleh anak dengan hambatan pendengaran. Namun karena kehilangan pendengaran yang dialaminya, membuat mereka kesulitan untuk berinteraksi dan berkomunikasi dengan lingkungan orang mendengar pada umumnya.

Hambatan pendengaran yang sering diistilahkan juga dengan tunarungu (hearing impairment) merupakan istilah umum yang menunjukkan pada kehilangan pendengaran dari yang ringan sampai berat sekali, yang secara garis besar mencakup tuli (deaf) dan kurang dengar (hard of hearing) orang tuli adalah seseorang yang kehilangan kemampuan mendengar sehingga menghambat proses informasi bahasa melalui pendengaran, baik memakai ataupun tidak memakai alat bantu dengar, sedangkan seseorang yang kurang dengar adalah seseorang yang biasanya dengan menggunakan alat bantu dengar, sisa pendengarannya cukup memungkinkan untuk memproses informasi bahasa melalui pendengaranya (Hallahan \& Kauffman,1991; Hardman et al.,1990).

Ahli lain yaitu Moores (2001) mengemukakan bahwa Orang tuli (deaf) adalah seseorang yang kehilangan kemampuan mendengar pada tingkat $70 \mathrm{~dB}$ ISO atau lebih sehingga ia tidak dapat mengerti pembicaraan orang lain melalui pendengarannya sendiri, tanpa atau menggunakan alat bantu mendengar, sedangkan orang kurang dengar (hardofhearing) adalah seseorang yang kehilangan kemampuan mendengar pada tingkat $35 \mathrm{~dB}$ sampai $69 \mathrm{~dB}$ ISO sehingga ia mengalami kesulitan untuk mengerti pembicaraan orang lain melalui pendengarannya sendiri, tanpa atau dengan alat bantu mendengar.

Dampak langsung dari kehilangan pendengaran terutama sejak lahir, adalah mereka mengalami hambatan dalam perkembangan bahasanya baik secara reseptif maupun ekspresif, sehingga menghambat kemampuannya untuk berkomunikasi secara lisan dengan lingkungan orang mendengar. Hal tersebut sesuai dengan apa yang dikemukakan oleh Hallahan \& Kauffman (2006) bahwa:"..people who are hearing impaired are gemerally deficient in the langage used by most people of the hearing society in the which the live." Kemampuan berbahasa lisan diperoleh melalui proses belajar meniru bunyi bahasa dari lingkungannya melalui pendengarannya. Oleh karena itu kehilangan pendengaran sejak lahir atau sebelum masa prabahasa, akan menghambat proses belajar berbahasa tersebut.

Dengan demikian dapat dikatakan bahwa dampak langsung dari hambatan pendengaran terutama sejak lahir atau masa prabahasa adalah terhambatnya kemampuan berbahasa, terutama berbahasa lisan baik secara reseptif maupun ekspresif. Kemampuan berbahasa lisan secara reseptif adalah kemampuan menangkap apa yang diucapkan pembicara, sedangkan kemampuan berbahasa lisan secara ekspresif, adalah kemampuan meyampaikan pesan melalui aktifitas bicara,

Mengingat kemampuan berbahasa lisan merupakan hasil dari proses penangkapan dan peniruan, maka dalam segi bahasa, anak tunarungu memiliki ciri yang khas yaitu; sangat terbatas dalam kosa kata, artikulasinya umumnya sulit dipahami, sulit mengartikan arti kiasan dan kata-kata yang abstrak.

Keterampilan berbahasa lisan merupakan keterampilan seseorang untuk mengungkapkan "sesuatu" dan memahami "sesuatu" yang diungkapkan oleh orang lain secara lisan. Keterampilan berbahasa lisan penting untuk dikuasai setiap orang, termasuk orang yang mengalami hambatan pendengaran.

Dalam suatu masyarakat, setiap orang saling berhubungan dengan orang lain dengan cara berkomunikasi. Tidak dapat dipungkiri bahwa keterampilan berbahasa lisan adalah salah satu unsur penting yang menentukan kesuksesan mereka dalam berkomunikasi.

Keterampilan berbahasa lisan mencakup keterampilan menyimak dan berbicara. Keterampilan menyimak dan berbicara sangat erat kaitannya dan bersifat resiprokal. Menyimak dapat didefinisikan sebagai suatu aktivitas yang mencakup kegiatan mendengarkan bunyi bahasa, mengidentifikasi, Jurnal Penelitian Pendidikan 
menilik, dan mereaksi atas makna yang terkandung dalam bahan simakkan (Tarigan, 1991).

Kegiatan menyimak pada anak dengan hambatan pendengaran terutama yang dikelompokan ke dalam tuli berbeda dengan anak mendengar pada umumnya. Pada anak mendengar kegiatan menyimak dilakukan dengan menangkap dan memahami apa yang disampaikan pembicara melalui pendengarannya, sedangkan pada anak dengan hambatan pendengaran terutama kelompok tuli melalui membaca ujaran. Membaca ujaran adalah menangkap dan memahami apa yang diucapkan pembicara dengan melihat gerak organ artikulasi dan mimik pembicara.

Aspek Bahasa lisan lainnya adalah berbicara. Tarigan (1981) menyatakan bahwa berbicara ialah suatu kemampuan mengucapkan bunyi-bunyi artikulasi atau kata-kata untuk mengekspresikan, menyatakan, serta menyampaikan pikiran, gagasan, dan perasaan. Ahli lain yaitu Arsjad dan Mukti (1993) mengemukakan bahwa kemampuan berbicara adalah kemampuan mengucapkan kalimat-kalimat untuk mengekspresikan, menyatakan, menyampaikan pikiran, gagasan, dan perasaan.

Keterampilan berbahasa anak dengan hambatan pendengaran harus dikembangkan melalui suatu program yang didasarkan pada hasil asesmen. Hernawati et al (2019) mengembangakan suatu program keterampilan berbahasa lisan melalui suatu penelitian. Program tersebut mencakup: dasar pemikiran, tujuan program. Ruang lingkup, subyek dan pengguna, adaptasi program, panduan pelaksanaan program serta evaluasi program.

Dasar pemikirannya adalah bahwa peserta didik penting untuk dikembangkan kemampuan berbahasa lisannya agar dapat berkomunikais lisan dengan lingkungan orang yang mendengar pada umumnya. Program tersebut bertujuan unuk meningkatkan keterampilan berbahasa lisan, sedangkan lingkup progrannya mencakup pengembangan aspek kemampuan membaca ujaran (reseptif), dan aspek berbicara (ekspresif). Subyeknya adalah peserta didik Jurnal Penelitian Pendidikan dengan hambatan pendengaran dan penggunanya adalah guru yang bersangkutan. Adaptasi program dilakukan berdasarkan kebutuhan belajar sebagai hasil asesmen. Program keterampilan berbahasa tersebut dapat diimplementasikan secara terpadu melalui tiga strategi, yaitu pertama, terpadu dalam pembelajaran tematik; kedua, terpadu dalam program khusus pendidikan anak dengan hambatan pendengaran, yaitu Pengembangan Komunikasi Persepsi Bunyi dan Irama (PKPBI); ketiga, melalui program khusus artikulasi. Oleh karena pentingnya pengembangan kemampuan berbahasa pada anak dengan hambatan pendengaran, maka hal itu perlu mendapatkan prioritas. Dengan meningkatnya kemampuan berbahasa, kemampuan berkomunikasi dengan lingkungan orang mendengar akan meningkat serta potensi-potensi lainnya dapat dikembangkan secara lebih optimal. Dengan demikian kunci dari pengembangan potensi anak tunarungu untuk mencapai pendidikan yang optimal adalah dengan kemampuan berbahasa, terutama bahasa lisan, baik reseptif maupun ekspresif.

Dalam upaya pengembangkan kemampuan berbahasa anak dengan hambatan pendengaran terebut, diperlukan suatu program terpadu yang disusun secara sistematis dan teruji efektivitasnya agar kemampuan berbahasa lisan mereka dapat berkembang secara optimal. Program tersebut perlu memberdayakan potensi atau berbagai sumber daya sekolah maupun mengintegrasikan berbagai strategi dalam upaya mengembangkan keterampilan berbahasa lisan anak dengan hambatan pendengaran, sebagaimana yang diemukakan dalam artikel ini.

\section{METODE PENELITIAN}

Tujuan umum penelitian ini adalah untuk mengetahui efektivitas program keterampilan berbahasa lisan pada anak dengan hambatan pendengaran. Oleh karena itu pendekatan penelitian yang digunakan dalam penelitian ini adalah pendekatan kuantitatif, sedangkan metode penelitiannya adalah eksperimen dengan posttest design.

Sampel penelitian ini adalah siswa kelas 3 SDLB di SLB Negeri Cicendo Bandung yang berjumlah 3 orang. Ketiga orang tersebut merupakan anak dengan hambatan 
pendengaran pada taraf sangat berat. Adapun Teknik pengambilan sampel nya adalah teknik purposive sampling. Teknik pengolahan datanya menggunakan Metode Uji Tanda Median, dengan rumus $\mathrm{P}(\mathrm{x}, \mathrm{p})=$ $\mathrm{P}(\mathrm{X} \leq \mathrm{x}$, bila $\mathrm{p}=1 / 2) \quad($ Zanten,1994).

\section{HASIL DAN PEMBAHASAN}

\subsection{Hasil}

Hasil penelitian ini meliputi adaptasi program Terpadu pengembangan keterampilan Berbahasa lisan serta efektivitas program berdasarkan hasil implementasi program.

\section{A. Adaptasi Program Terpadu}

Pengembangan Keterampilan Berbahasa lisan.

Program Terpadu pengembangan keterampilan berbahasa merupakan suatu program dengan memadukan beberapa strategi dalam mengimplementasikannya. Strategi pertama, terpadu dalam pembelajaran tematik; kedua, terpadu dalam program khusus PKPBI, dan ketiga, melalui Program Khusus Artikulasi. Program tersebut diadaptasikan dengan hasil asesmen kemampuan berbahasa lisan. Sebelum dilakukan penyusunan program, terlebih dahulu dilakukan asesmen yang meliputi aspek menyimak atau membaca ujaran (aspek reseptif) dan berbicara (aspek ekspresif) dengan sub aspek masing-masing mencakup semantic, fonologi dan sintaksis. Hal tersebut mengacu pada salah satu pengukuran komprehensif terhadap kemampuan berbahasa lisan yang dikemukakan McLoughlin \& Lewis (2008) yaitu Test of Language DevelopmentPrimary, yang mengukur aspek reseptif dan ekspresif dalam dimensi semantik, fonologi, dan sintak. Hasil asesmen dianalisis, sehingga menemukan kebutuhan belajarnya, yang kemudian menjadi materi adaptasi program.

Adaptasi program ini didasarkan pada hasil asesmen kemampuan berbahasa lisan siswa kelas 3 di SLB Negeri Cicendo Bandung yang berjumlah 3 orang. Hasil asesmen kemampuan berbahasa lisan yang dilakukan pada siswa dengan hambatan pendengaran kelas 3 di SLB Negeri Cicendo Bandung menunjukan masih rendah atau masuk kategori cukup dari empat kategori (kurang, cukup, baik, dan baik sekali). Berdasarkan analisis terhadap hasil asemen tersebut, diketahui kebutuhan belajarnya, yang selanjutnya dilakukan adaptasi program. Namun, dalam penelitian ini, tidak semua kebutuhan belajar siswa (khususnya dalam kemampuan ekspresif fonologi) diakomodir dalam program ini, mengingat keterbatasan waktu penelitian. Jadi, dalam implementasi program ini ditekankan pada pengembangan kemampuan pengucapan beberapa fonem saja. Adaptasi program tersebut dapat dilihat pada tabel berikut ini.

Tabel 1. Adaptasi Program Terpadu Keterampilan Berbahasa Lisan Anak Dengan Hambatan Pendengaran Kelas 3

\begin{tabular}{|c|c|c|c|c|c|}
\hline Kompetensi & Indikator & Materi & Pendekatan/ Materi & Evaluasi & Sumber \\
\hline \multicolumn{6}{|c|}{ Keterampilan Membaca Ujaran ( Aspek Reseptif) } \\
\hline $\begin{array}{l}\text { 1.Mampu } \\
\text { memahami } \\
\text { ujaran kata }\end{array}$ & $\begin{array}{l}\text { Mampu } \\
\text { menunjukan } \\
\text { gambar kata benda } \\
\text { dan kata kerja } \\
\text { dengan tepat }\end{array}$ & $\begin{array}{l}\text { Membaca ujaran } \\
\text { kata benda seperti : } \\
\text { gelas,nanas, kursi } \\
\text { sendok, pensil, } \\
\text { pisang, tangan; serta } \\
\text { kata kerja seperti: } \\
\text { tidur,makan, } \\
\text { membaca, } \\
\text { mengepel, dan } \\
\text { menggosok gigi. }\end{array}$ & $\begin{array}{l}\text { Klasikal } \\
\text { Metode Maternal } \\
\text { Reflektif } \\
\text { Visual } \\
\text { Penempatan } \\
\text { fonetik }\end{array}$ & $\begin{array}{l}\text { Tes kinerja } \\
\text { : kosa kata } \\
\text { gambar. }\end{array}$ & $\begin{array}{l}\text { Bunawan, } \\
\text { L.\&Yuwati, } \\
\text { C. S. (2000). } \\
\text { Penguasaan } \\
\text { Bahasa Anak } \\
\text { Hambatan } \\
\text { pendengaran } \\
\text {. Jakarta: } \\
\text { Yayasan } \\
\text { santi Rama. }\end{array}$ \\
\hline $\begin{array}{l}\text { 2.Mampu } \\
\text { membedakan } \\
\text { kata }\end{array}$ & $\begin{array}{l}\text { Mampu } \\
\text { mendiskriminasika } \\
\mathrm{n} \text { ujaran kata -kata } \\
\text { yang mengandung } \\
\text { fonem } \mathrm{j} \text { dan } \mathrm{r} \text {; } \mathrm{h}\end{array}$ & $\begin{array}{l}\text { Diskriminasi ujaran } \\
\text { kata-kata yang } \\
\text { mengandung fonem } \\
\text { j dan r; h dan m; } \\
\text { vocal idan e; serta u } \\
\text { dan a, sert a dan i }\end{array}$ & $\begin{array}{l}\text { Klasikal } \\
\text { Metode Maternal } \\
\text { Reflekisual } \\
\text { Penempatan } \\
\text { fonetik }\end{array}$ & $\begin{array}{l}\text { Tes lisan: } \\
\text { Diskriminas } \\
\text { i kata. }\end{array}$ & $\begin{array}{l}\text { Rusyani, E. } \\
\text { (2017). } \\
\text { Artikulasi } \\
\text { dan } \\
\text { Optimalisasi }\end{array}$ \\
\hline
\end{tabular}




\begin{tabular}{|c|c|c|c|c|c|}
\hline & $\begin{array}{l}\text { dan m; vocal idan } \\
\text { e; serta u dan a. }\end{array}$ & & & & \multirow{6}{*}{$\begin{array}{l}\text { Fungsi } \\
\text { Pendengaran. } \\
\text { Bandung: } \\
\text { Departemen } \\
\text { Pendidikan } \\
\text { Khusus FIP- } \\
\text { UPI. } \\
\text { Sumardjo, H. } \\
\text { (ed). (2013). } \\
\text { Didaktik } \\
\text { Metodik } \\
\text { Pemerolehan } \\
\text { Kemampuan } \\
\text { Berbahasa } \\
\text { Anak } \\
\text { Tunarungu } \\
\text { Sekolah } \\
\text { Dasar. } \\
\text { Jakarta : } \\
\text { Pohon } \\
\text { Cahaya } \\
\text { (Anggota } \\
\text { IKAPI) } \\
\text { Sumardjo, H. } \\
\text { (ed). 2013. } \\
\text { Didaktik } \\
\text { Metodik } \\
\text { Pelatihan } \\
\text { Wicara Anak } \\
\text { Tunarungu. } \\
\text { Jakarta: } \\
\text { Pohon } \\
\text { Cahaya } \\
\text { (Anggota } \\
\text { IKAPI). }\end{array}$} \\
\hline $\begin{array}{l}\text { 3.Mampu } \\
\text { memahami } \\
\text { kalimat }\end{array}$ & $\begin{array}{l}\text { Mampu membaca } \\
\text { ujaran kalimat } \\
\text { sederhana dengan } \\
\text { respon penunjukan } \\
\text { gambar. }\end{array}$ & $\begin{array}{l}\text { Membaca ujaran } \\
\text { kalimat sederhana. }\end{array}$ & $\begin{array}{l}\text { Klasikal } \\
\text { visual } \\
\text { Metode Maternal } \\
\text { Reflektif }\end{array}$ & $\begin{array}{l}\text { Tes kinerja: } \\
\text { pemahaman } \\
\text { kalimat }\end{array}$ & \\
\hline \multicolumn{5}{|c|}{ Keterampilan Berbicara ( Aspek Ekspresif) } & \\
\hline $\begin{array}{l}\text { 4.Mampu } \\
\text { menjelaskan } \\
\text { makna kata } \\
\text { secara lisan. }\end{array}$ & $\begin{array}{l}\text { Mampu } \\
\text { menjelaskan makna } \\
\text { kata secara lisan } \\
\text { dengan lebih dari } \\
\text { satu kata }\end{array}$ & Kosa kata Lisan & $\begin{array}{l}\text { Klasikal } \\
\text { Multisensoris } \\
\text { Metode Maternal } \\
\text { Reflektif } \\
\text { Imitasi } \\
\text {-resitasi. }\end{array}$ & $\begin{array}{l}\text { Tes lisan : } \\
\text { kosa kata } \\
\text { lisan }\end{array}$ & \\
\hline $\begin{array}{l}\text { 5.Mampu } \\
\text { mengucapka } \\
\text { n Fonem }\end{array}$ & $\begin{array}{l}\text { Mampu } \\
\text { mengucapkan } \\
\text { fonem/konsonan } \\
\text { bilabial, labio } \\
\text { dental, dental, } \\
\text { laringal, dan } \\
\text { palatal. }\end{array}$ & $\begin{array}{l}\text { Latihan pengucapan } \\
\text { fonem/konsonan } \\
\text { IM } \\
\text { konsonan bilabial: } \\
\text { m (t), w (aw,t). } \\
\text { labio- dental: f (aw) } \\
\text { Dental:t (t), d (aw), } \\
\text { n (aw,t,ak); } \\
\text { Laringal: h (aw,t,ak) } \\
\text { palatal: c (aw,t); } \\
\text { dan velum : g (aw) } \\
\text { FI } \\
\text { konsonan bilabial: } \\
\text { m (aw,t, ak); w } \\
\text { (aw,t). } \\
\text { labio- dental: f (aw) } \\
\text { Dental:t (aw,t); n } \\
\text { (aw,t,ak); } \\
\text { Laringal: h } \\
\text { (aw,t,ak); dan } \\
\text { velum: g (aw) } \\
\text { FZ } \\
\text { konsonan bilabial: } \\
\text { m (aw,t,ak),w } \\
\text { (aw,t). labio- dental: } \\
\text { f (aw) } \\
\text { Dental: t (t), d } \\
\text { (aw,t), n (aw,t,); } \\
\text { Laringal: h (aw,t,) } \\
\text { palatal: c (aw,t). }\end{array}$ & $\begin{array}{l}\text { Pendekatan } \\
\text { individual. } \\
\text { Metode: } \\
\text { - Global } \\
\text { berdiferensiasi } \\
\text { - Analisis sintetis } \\
\text { - Suara ujaran } \\
\text { - Multisensoris } \\
\text { - Fonetik } \\
\text { - Penempatan } \\
\text { fonetik } \\
\text { - Moto kinestetik/ } \\
\text { manipulasi } \\
\text { - Demonstrasi } \\
\text { - Imitasi } \\
\text { - Resitasi }\end{array}$ & $\begin{array}{l}\text { Tes kinerja: } \\
\text { pengucapan } \\
\text { fonem. }\end{array}$ & \\
\hline $\begin{array}{l}\text { 6.Mampu } \\
\text { menirukan } \\
\text { ucapan } \\
\text { kalimat yang } \\
\text { diujarkan }\end{array}$ & $\begin{array}{l}\text { Mampu menirukan } \\
\text { ucapan kalimat } \\
\text { sederhana }\end{array}$ & $\begin{array}{l}\text { Latihan } \\
\text { berbicara/meniruka } \\
\text { n ucapan kalimat } \\
\text { sederhana. }\end{array}$ & $\begin{array}{l}\text { Pendekatan: } \\
\text { Klasikal/individual } \\
\text { MMR, } \\
\text { Multisensoris } \\
\text { Imitasi } \\
\text { resitasi. }\end{array}$ & $\begin{array}{l}\text { Tes lisan } \\
\text { imitasi } \\
\text { kalimat. }\end{array}$ & \\
\hline
\end{tabular}

\section{B. Panduan Implementasi Program}

Program keterampilan berbahasa dapat diimplementasikan melalui tiga strategi, yaitu: pertama, Terpadu dalam pembelajaran tematik; kedua, terpadu dalam program khusus Pengembangan Kemampuan Persepsi Bunyi dan Irama; ketiga, melalui program khusus Artikulasi. Pada dasarnya Program khusus Artikulasi ini merupakan bagian dari Program khusus Pengembangan Kemampuan Persepsi Bunyi dan Irama, tetapi dilaksanakan secara individual di ruang khusus.

1. Terpadu dalam Pembelajaran Tematik. Implementasi program secara terpadu dalam pembelajaran tematik dilakukan secara klasikal 
dengan menggunakan Metode Maternal Reflektif (MMR), yaitu metode pembelajaran bahasa dengan menggunakan percakapan sebagai porosnya. Dalam peaksanaannya MMR mencakup berbagai tahapan, yang meliputi: tahap percakapan dari hati ke hati, visualisasi percakapan, penyusunan bacaan deposit / membaca ideovisual, percakapan linguistik, serta refleksi. Rancangan pembelajaran tematik dengan menerapkan Metode Maternal Reflektif ini mengacu pada hasil penelitian Hernawati et al (2018) tentang Pembelajaran Maternal Reflektif dalam meningkatkan komunikaksi verbal anak dengan hambatan pendengaran, serta hasil penelitian Hernawati et al (2020) tentang Adaptasi Program Keterampilan Bebahasa Lisan Anak dengan Hambatan Pendengaran. Rancangan pembelajarannya terdiri dari tiga tahap. Pertama tahap Pra pembelajaran; kedua, tahap Pembelajaran; dan ketiga, tahap Pasca Pembelajaran. Rancangan pembelajaran tersebut sifatnya fleksibel yang dapat diterapkan dalam berbagai materi pembelajaran.

\section{Tabel 2. Rancangan Pembelajaran Dengan Menerapkan Metode Maternal Reflektif}

Tahap Kegiatan

1.Pra Pembelajaran

a) Menelaah kebutuhan belajar siswa.

b) Memilih tema $\&$ sub tema yang ada dalam kurikulum yang sesuai dengan kebutuhan belajar peserta didik.

c) Mempersiapkan media yang diperkirakan sesuai dengan percakapan yang akan terjadi.

d) Merencanakan bentuk stimulasi apa yang akan diberikan sehingga anak menemukan bahan/objek untuk dipercakapkan.

1. Pembelajaran

a.Pendahuluan a. Pengkondisian siswa yang duduk di kursi dengan posisi setengah lingkaran, dan guru duduk di depan siswa.

b. Pemberian stimulasi agar terjadi percakapan.

b. Inti

1) Percakapan dari a. Siswa bercakap-cakap dengan guru dan siswa lainnya melalui provokasi guru seputar Hati ke Hati peristiwa yang sedang terjadi (situasional), atau pengalaman sebelumnya.

b. Guru mengarahkan Percakapan agar selaras dengan tema yang sudah ditentukan, tetapi tetap menjaga spontanitas berpikir peserta didik dalam percakapan tersebut.

c.Dalam percakapan tersebut, seringkali siswa mengungkapkan pesan/pikiran dengan ucapan yang tidak jelas, disertai isyarat. Oleh karena itu guru menerapkan teknik tangkap dan peran ganda, yaitu menangkap pesan atau pikiran yang diungkapkan siswa melalui vokalisasi seadanya atau dengan bahasa isyarat, kemudian membahasakannya, dan menanggapinya. Dalam percakapan ini guru menerapkan motto MMR “ Apa yang ingin kau katakan katakanlah begini”. Artinya guru membahasakan apa yang ingin dikatakan siswa. Percakapan dapat dilakukan sekitar 15-20 menit.

2)Visualisasi a. Guru bersama siswa meninjau kembali percakapan yang baru saja terjadi dan menuliskan Percakapan percakapan tersebut di papan tulis dengan huruf sambung dan menggunakan kalimat langsung (siapa mengatakan apa).

b. Guru memberikan lengkung frase/kelompok aksen pada hasil visualisasi percakapan. Lengkung frase/kelompok aksen merupakan garis lengkung di bawah frase atau kelompok kata bagian dari kalimat, yang menunjukan adanya intonasi.

c.Siswa dibimbing guru membaca bacaan sebagai hasil visualisasi percakapan sesuai lengkung frase/kelompok aksen'

d.Mengolah visualisasi perakapan, antara lain dengan: membantu siswa mengartikan kalimat dengan peragaan, gambar dan mencari kosa kata baru, dsb.

3)Penyusunan Bacaan Deposit \& Membaca Ideovisual a. Berdasarkan hasil visualisasi percakapan, guru Menyusun suatu bacaan yang menarik, yang tidak hanya berupa kalimat langsung, tetapi juga ditambahkan kalimat tidak langsung untuk memperjelas bacaan.

b. Secara brsama-sama, siswa membaca bacaan deposit dengan bimbingan guru, kemudian memberi judul bacaan.

c.Siswa secara individual dibimbing untuk membaca bacaan deposit tersebut satu kalimat demi satu kalimat. Setelah membaca satu kalimat, siswa dengan menghadap ke temannya mengulangi bacaan tadi.

d.Guru membetulkan ujaran siswa.

e.Siswa dan guru mengolah bacaan yang ada di papan tulis melalui tanya jawab, mengucapkan\& menunjukkan kata, mepraktekkan, menuliskan, dan lain sebagainya. 


\begin{tabular}{ll}
\hline $\begin{array}{l}\text { 4) Refleksi \& } \\
\begin{array}{l}\text { Percakapan } \\
\text { Linguistik }\end{array}\end{array}$ & $\begin{array}{l}\text { a. Siswa diminta menjawab pertanyaan mengenai isi bacaan. } \\
\text { b. Siswa diminta untuk membaca ujaran kata, kemudian menunjukan gambar/ tulisan } \\
\text { yang sesuai. }\end{array}$ \\
& $\begin{array}{l}\text { c. Siswa diminta untuk membaca ujaran dua kata yang berbeda/sama, kemudian } \\
\text { menyampaikan apakah dua kata tersebut sama atau berbeda. }\end{array}$ \\
& $\begin{array}{l}\text { d. Guru menunjuk /menuliskan kata atau kalimat yang mengandung topik tata bahasa, } \\
\text { kemudian membahasnya. }\end{array}$ \\
\hline c. Penutup & $\begin{array}{l}\text { Guru dan siswa menyimpulkan hasil pembelajaran dan mengakhiri pembelajaran dengan } \\
\text { doa dan salam }\end{array}$ \\
\hline 3.Pasca Pembelajaran & $\begin{array}{l}\text { Guru membuat Jurnal/laporan pembelajaran, yang menggambarkan kegiatan yang telah } \\
\text { dilakukan, terutama hasil visualisasi percakapan/bacaan deposit serta evaluasi yang } \\
\text { dilakukan. }\end{array}$
\end{tabular}

Berdasarkan rancangan pembelajaran yang sifatnya umum tersebut maka disusun Rancangan Pelaksanaan Pembelajaran Tematik untuk masing-masing pertemuan. Adapun format RPP tematik ini pada dasarnya sama denga RPP tematik pada umumnya, hanya prosedur atau sintak pembelajaranya mengacu pada pembelajaran dengan Metode Maternal Reflektif tadi.

\section{Terpadu dalam Program Khusus Pengembangan KomunikasiPersepsi Bunyi dan Irama}

Program keterampilan berbahasa lisan yang terpadu dalam bidang Pengembangan Komunikasi, Persepsi Bunyi dan Irama, lebih diarahkan untuk mengembangkan kemampuan membaca ujaran (aspek reseptif) dan berbicara (aspek ekspresif). Perencanaan pelaksanaan program keterampilan berbahasa lisan ini bisa menggunakan Rencana Pelaksanaan Pembelajaran (RPP) yang reguler, tetapi dengan memperhatikan kemampuan siswa secara individual. Di samping itu dapat juga menggunakan rancangan Program Pembelajaran yang diindividualisasikan yang mengacu pada Individualized Educational Program (IEP). Komponen dari IEP ini adalah setidaknya mencakup: identitas siswa, Kemampuan siswa saat ini, Tujuan Pembelajaran Umum/Kompetensi; Tujuan Pembelajaran Khusus/Indikator; Deskripsi layanan yang mencakup materi, metode, media, serta kegiatan Pembelajaran; Alokasi waktu, serta evaluasi.

3. Program Khusus Artikulasi

Program Khusus Artikulasi pada dasarnya merupakan bagian dari program khusus Pengembangan Komunikasi, Persepsi
Bunyi dan Irama, Tetapi hanya difokuskan pada pelatihan pengucapan fonem yang dilaksanakan secara individual di rungan khusus. Pembelajaran secara individual tersebut sangat penting dilakasanaan pada kelas dasar agar pelatihan bisa lebih efektif, mengingat pada dua strategi sebelumnya, pembelajaran dilaksanakan secara klasikal. Rancangan pembelajarannya menggunakan IEP, yang merupakan program untuk masingmasing siswa dan materi latihannya disesuaikan dengan hasil asesmen siswa yang bersangkutan.

Setelah program selesai dilaksanakan, dilakukan evaluasi program yang mencakup evaluasi proses dan hasil. Evaluasi proses dilakukan untuk mengetahui keterlaksanaan program. Evaluasi proses dapat dilakukan melalui observasi. Evaluasi hasil dimaksudkan untuk mengetahui efektivitas program, yang dapat dilakukan melalui asesmen kedua atau posttest.

\section{Hasil Uji Efektifitas Program}

Berikut ini adalah hasil posttest keterampilan berbahasa lisan anak dengan hambatan pendengaran kelas 3 .

Rumusan bentuk hipotesis penelitian yang akan diuji satu pihak kanan adalah:

$\mathrm{H}_{0}$ :Implementasi program keterampilan berbahasa lisan dapat meningkatkan keterampilan berbahasa lisan pada anak dengan hambatan pendengaran kelas 4 mencapai $75 \%$ atau dengan nilai 75 .

$\mathrm{H}_{1}$ :Implementasi program keterampilan berbahasa lisan dapat meningkatkan keterampilan berbahasa lisan pada anak dengan hambatan pendengaran kelas 4 dengan ketercapaian di atas $75 \%$ atau di atas nilai 75 . 


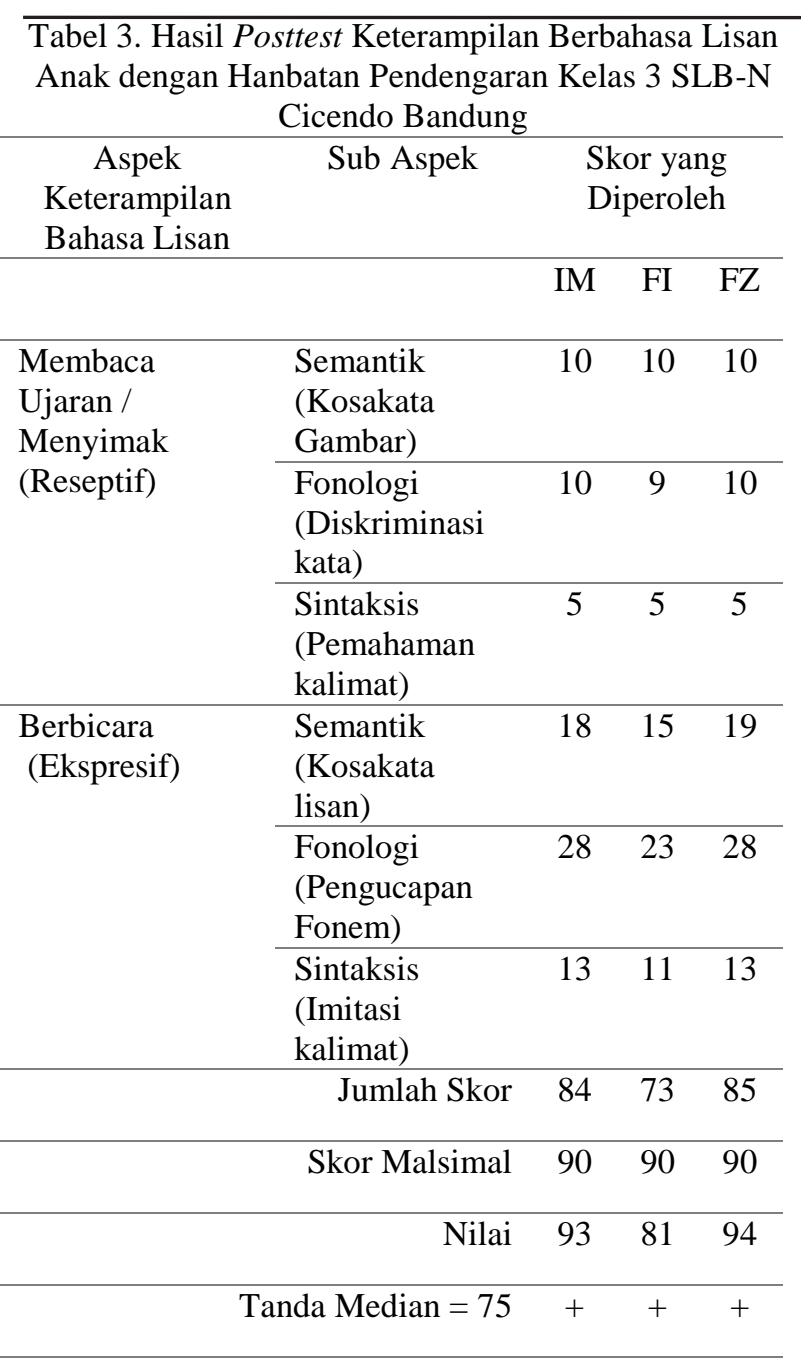

Rumusan bentuk hipotesis statistik uji tanda satu pihak kanan;

$$
\begin{aligned}
& \mathrm{H}_{0}: \mathrm{m}_{0}=75 \\
& \mathrm{H}_{1}: \mathrm{m}_{0}>75 \\
& \mathrm{X}=\text { bertanda positif } \\
& \mathrm{n}=3
\end{aligned}
$$

Rumus

$$
\mathrm{P}(\mathrm{x}, \mathrm{p})=\mathrm{P}(\mathrm{X} \leq 5 \text {, bila } \mathrm{p}=1 / 2)
$$

$\mathrm{n}=3, \mathrm{x}=3, \mathrm{p}=1 / 2$ dalam table peluang binomial $=1$

\section{Dengan kriteria}

Penolakan $\mathrm{H}_{0}$ uji satu pihak kanan adalah proporsi atau peluang yang bertanda tambah lebih besar daripada $1 / 2$ atau $\mathrm{P}<\alpha$.

Berdasarkan tabel peluang binomial diperoleh $=1$, sedangkan kriteria peluang bertanda positif lebih besar $1 / 2$, dengan demikian Ho ditolak.

Dengan menggunakan rumus $b$.

Statistik uji untuk pengujian hipotesis statistik adalah

$\mathrm{P}(\mathrm{x}, \mathrm{p})=\mathrm{P}(\mathrm{X} \leq \mathrm{x}$, bila $\mathrm{p}=1 / 2)$,

$P$ hitung dengan $x=3$ (banyak tanda

$$
\begin{aligned}
& \text { positip) } \\
& \mathrm{n}=3 \\
& \mathrm{P}=\mathrm{P}(\mathrm{X} \geq 3, \text { bila } \mathrm{p}=1 / 2)=1-\mathrm{P}(\mathrm{X} \leq 3, \\
& \text { bila } \mathrm{p}=1 / 2) \\
& \mathrm{P}=1-1 \text { maka } \mathrm{P}=0
\end{aligned}
$$

Hasil $\mathrm{P}$ hitung $=0$, dengan taraf signifikansi $\alpha=0,05$, maka $\mathrm{P}$ hitung lebih kecil dari harga $\alpha,(\mathrm{P}=0>0,05)$. Dengan kriteria daerah penolakan $\mathrm{H}_{0}$ bahwa tolak $\mathrm{H}_{0}$ jika $\mathrm{P}<\alpha$, maka menolak $\mathrm{H}_{0}$ dan menerima $\mathrm{H}_{1}$ : $\mathrm{m}_{0}>75$.

Berdasarkan hasil pengujian hipotesis tersebut, dapat disimpulkan bahwa implementasi program keterampilan berbahasa lisan dapat meningkatkan keterampilan berbahasa lisan pada anak dengan hambatan pendengaran kelas 4 dengan ketercapaian di atas $75 \%$ atau di atas nilai 75 .

\subsection{Pembahasan}

Hasil pengujian efektivitas program menunjukan bahwa program terpadu tersebut efektif untuk meningkatkan keterampilan berbahasa lisan anak dengan hambatan pendengaran kelas 3 SLB-N Cicendo Bandung. Pengujian efektivitas tersebut diakukan melalui implementasi program yang dilakukan selama lima pertemuan, dengan rincian: dua kali melalui pembelajaran tematik; dua kali melalui program PKPBI, dan satu kali melalui program khsusu artikulasi.

Keterampilan berbahasa lisan yang dikembangkan meliputi aspek menyimak atau membaca ujaran (aspek reseptif) dan berbicara (aspek ekspresif) dengan sub aspek masingmasing mencakup semantik, fonologi dan sintaksis. Analisis efektivitas program terpadu ini dapat ditinjau dari beberapa hal.

Pertama, dalam program terpadu tersebut menerapakan Metode Maternal Reflekif dalam pembelajaran tematik untuk mengembakan keterampilan berbahasa. Pada dasarnya Metode Maternal Reflektif ini adalah metode pengajaran Bahasa melalui percakapan. Uden (Bunawan \&Yuwati,2000) mengemukakan bahwa percakapan merupakan kunci pengembangan bahasa anak tunarungu/anak dengan hambatan pendengaran.

Melalui Metode Maternal Reflektif ini bahasa anak dengan hambatan pendengaran dikembangkan dalam suasana yang alamiah, 
dalam percakapan menganai berbbagai hal yang dialami dan dipikirkannya, sehingga lebih mudah memahami Bahasa.

Dengan demikian metode tersebut dipandang efektif untuk mengembangkan kemampuan berbahasa anak dengan hambatan pendengaran. Bukti dari dari kefektifan metode tersebut antara lain ditunjukan dengan hasil penelitian Prasetyo et al (2017) yang mengemukakan bahwa penerapan Metode Maternal Reflektif, efektif dalam meningkatkan minat belajar siswa serta meningkatkan pemahaman bahasa.

Bukti yang lainnya adalah hasil penelitian Zulmiyetri (2017) yang menunjukan bahwa penggunaan Metode Maternal Reflektif dan penggunaan media yang menarik, kemampuan berbahasa lisan anak dengan hambatan pendengaran mengalami peningkatan.

Demikian juga Hernawati et al. (2018) membuktikan melalui penelitiannya, bahwa pembelajaran maternal reflektif dapat meningkatkan kemampuan komunikasi verbal anak dengan hambatan pendengaran.

Kedua, Implementasi program ini terpadu dengan prrogram khusus Pengembangan Komunikasi, Persepsi Bunyi dan Irama, yang dalam pelaksanaannya didasarkan pada hasil asesmen, sehingga layanan pembeajarannya sesuai dengan kebutuhan belajarnya. Dengan demikian, layanan tersebut dipandang efektif. Hal tersebut sesuai dengan pendapat McLoughlin \& Lewis (2008), bahwa berdasarakan informasi yang diperoleh dari hasil asesmen, guru akan dapat menyusun program pembelajaran yang bersifat realitas sesuai dengan kenyataan objektif.

Ketiga, Implementasi program melalui program khusus artikulasi secara individual dengan menggunakan program pembelajaran yang diindividualisasikan. Latihan artikulasi atau pelafalan fonem dipandang lebih efektif dilaksanakan secara individual dibanding secara klasikal, karena kemampuan artikulasi siswa ini sangat variatif, sehingga layanannya harus disesuaikan dengan kemampuan masing-masing siswa.

Dengan demikian, implementasi melalui tiga strategi tersebut sangat mendukung keberhasilan peningkatan keterampilan Jurnal Penelitian Pendidikan berbahasa lisan, sehingga dapat dikatakan bahwa program terpadu tersebut efektif untuk meningkatkan keterampilan anak dengan hambatan pendengaran dalam berbahasa lisan.

\section{KESIMPULAN}

Anak dengan hambatan pendengaran penting sekali untuk dikembangkan keterampilan berbahasa lisannya, untuk meningatkan kemampuan berkomunikasi dengan lingkungn orang mendengar pada umumnya serta untuk mengembangkan berbagai potensi lainnya. Keterampilan berbahasa lisan tersebut dapat dapat dikembangkan dengan mengimplementasikan program terpadu, yang telah terbukti efektivitasnya.

Efektivitas program tersebut diperoleh, karena dalam program tersebut memadukan Metode Maternal Reflektif, atau metode percakapan yang sesuai dengan kemampuan anak dengan hambatan pendengaran, Di samping itu program ini didasarkan pada hasil asesmen, sehingga materi layanannya sesuai dengan kebutuhan belajarnya.

Selanjutnya implementasi program terpadu melalui pembelajaran secara individual pada program khusus artikulasi, betul-betul memberikan layanan yang sesuai dengan kemampuan masing-masing siswa.

Berdasarkan hasil penelitian ini, pihak sekolah atau guru disarankan untuk mengimplementasikan program terpadu tersebut dalam mengembangkan keterampilan berbahasa lisan melalui tiga strategi.

Ketigra strategi tersebut akan bersinergi dalam mencapai apa yang diharapkan, yaitu meningkatnya keterampilan berbahasa lisan anak dengan hambatan pendengaran. Untuk dapat mengimplementasikan program terpadu ini, guru direkomendasikan untuk melakukan asesmen kemampuan berbahasa lisan pada siswanya, kemudian mengadaptasikan program terpadu dengan kebutuhan belajar yang diperoleh melalui analisis hasil asesmen.

Dengan demikian guru dapat mengimplementasikan program yang sesuai dengan kebutuhan belajar siswa dan dengan strategi yang teruji efektivitasnya. 


\section{DAFTAR PUSTAKA}

Arsjad, M. G., \& Mukti, U. S. (1993). Pembinanan Keterampilan Berbicara Berbahasa Indonesia, Jakarta: Erlangga.

Bunawan, L., \& Yuwati, C. S. (2000). Penguasaan Bahasa Anak Hambatan pendengaran. Jakarta: Yayasan Santi Rama.

Hallahan, D. P. \& Kouffman, J. M. (1991). Exceptional Children Introduction to Special Education (fifth ed.). New Jersey: Prentice Hall International Inc.

Hallahan, D. P. \& Kouffman, J. M. (2006). Exceptional Learners Introduction to Special Education (Tenth ed.). Boston: Pearson Education Inc.

Hardman, M., Drew, C. J., Egan, M. W., \& Wolf, B. (1990). Human Exceptionality: 3rd Edition. Boston: Allyn and Bacon.

Hernawati, T., Aprilia, I. D., \& Gunawan, D. (2020). Adaptation of Oral Language Skills Program in Hearing Impaired Children at SLBN Cicendo Bandung. Borderless Education as a Challenge in the 5.0 Society: Proceedings of the 3 rd International Conference on Educational Sciences (ICES 2019), Nopember 7, 2019 Bandung Indonesia.

Hernawati, T., Rusyani, E., \& Heryati, E. (2018). Maternal Reflective Learning in Improving the Verbal Communication of Children with Haring Impairment. Proceedings of International Conference on Sustainability Development Goals for Disabilities. Diakses dari http://appkhi.or.id/wpcontent/uploads/2020/05/Proceedings-ICSDGD.pdf.

McLoughlin, J. A., \& Lewis, R. B. (2008). Assessing Students with Special Needs (Seventh ed.). New Jersey: Pearson Prentice Hall.

Moores, D. F. (2001). Educating the Deaf; Psychology, Principles, and Practices. (fifth ed.). Boston: Houghton Mifflin Com

Prasetyo, Asrowi, \& Sunardi (2017). The Using Reflective Maternal Method to Improve Language Learning and Understanding of Hearing Impairment Students in Grade 2 Pemalang State Extraordinary Schools-SLB Negeri Pemalang, Indonesia. European Journal of Special Education Research, Volume 2, Issue 2, Pages 25-34.

Sumardjo, H. (2013). Didaktik Metodik Pemerolehan Kemampuan Berbahasa Anak Tunarungu Sekolah Dasar. Jakarta: Pohon Cahaya (Anggota IKAPI)

Tarigan, D. (1991). Pendidikan Bahasa Indonesia 1. Jakarta: DEPDIKBUD.

Tarigan, H. G. (1981). Berbicara sebagai suatu keterampilan berbahasa. Bandung: Angkasa.

Zanten, W. V. (1994). Statistika untuk Ilmu Sosial. Jakarta: Gramedia.

Zulmiyetri. (2017). Metoda Maternal Reflektif (MMR) untuk Meningkatkan Kemampuan Bahasa Lisan Anak Tunarungu. Jurnal Konseling dan Pendidikan, 5(2). DOI: https://doi.org/10.29210/117500. 